\author{
GyUla KoI*
}

\title{
The First Three Decades of Legal Reforms in the People's Republic of China (1978/1979-2008/2009)**
}

\begin{abstract}
This paper outlines the current problems of the different levels of Chinese administrative reforms implemented in the first three decades from 1978-1979 to 2008-2009. The discipline of legal sinology is a relatively new scientific field in Hungary and we have adopted its methods in the research leading to this study. The first and second parts of the study are based on the grounds of the most modern historical sources on the antecedents of the reforms. The third part of this work analyses the reform of the State Constitution of the People's Republic of China. The most important result of this process was the recognition and protection of basic human rights under the State Constitution of the People's Republic of China. The fourth part highlights recent administrative reforms from period to period. The administrative reform included the reform of the State Council (Government of the People's Republic of China), as a result of which the number of the staff of the State Council diminished from 51,000 to 16,700 . The final part of this study introduces the reforms of Civil Law. In 1949, the Guomindang Laws (inclusive of the Civil Code) were suspended by Chinese Communists; therefore, putting the new Civil Code into force was urgently necessary. The Draft Civil Code was completed in 2004.
\end{abstract}

Keywords: legal sinology, law in the People's Republic of China, Chinese legal reforms, constitutional reforms in the People's Republic of China, amendments of the State Constitution of the People's Republic of China, administrative reforms, the number of the staff of Chinese public administration, reforms of civil law, Maoism, Chinese communists, Guomindang, human rights.

\section{Preliminary Notes}

One of the most intriguing phenomena in the contemporary world is the development implemented by the People's Republic of China (hereinafter: PRC). That entails the requirement of a change in the conception of the tasks within legal sinology. However, Hungarian legal sinology including its scattered antecedents is being shaped in statu nascendi. ${ }^{1}$ Without the revealing analyses conducted in legal studies, administrative sciences, economics, political science and sociology the processes taking place in the most populated country of the world with the fourth largest territory cannot be understood. The undergoing progress in PRC raises questions like what position and role PRC will take with respect to emerging economies such as Brazil and India, what effects the growth of PRC will entail with respect to such significant powers such as Russia or the European Union seeking its identity, furthermore, in what way the USA currently safely considering

* Junior research fellow, Institute for Legal Studies of the Hungarian Academy of Sciences, H-1014 Budapest, Országház u. 30; tutor, Department of Defence Administration of the Military Technical Faculty at the National Defence University, H-1101 Budapest, Hungária krt. 9-11.

Email: koigyula@gmail.com

** This paper was prepared within the framework of the long-term research program of the Institute for Legal Studies of the Hungarian Academy of Sciences (Division of Administrative Law) titled "Major Administrative System of the World (2010-2014)".

1 As for the term of legal sinology, see Koi, Gy.: Jogi sinológia (Legal Sinology). In: Lamm, V. (ed.): Jogi lexikon (Encyclopaedia of Legal Studies). Budapest, 2009, 350. Second, enlarged and revised edition. 
itself to be the first superpower of the world will be able to interfere with this process. The objectives of this study are to focus on the continual reforms of PRC taking place for the past 30 years with special regard to the legal and public administrative reforms and to allow insight into the results of economic reforms, as well. China has grown from an underdeveloped agricultural country into a superpower determining world processes, whereas, it has not changed concerning its spiritual roots (Maoism), although, its political system has become more compliant and it has accomplished outstanding economic and social achievements. These achievements bid fair prospects of high economic growth even during the world recession bringing the world to heel. ${ }^{2}$ It cannot be precluded that in view of the current processes unless their tendency changes, PRC may become the most significant power of the world within a few decades. In parallel to these processes, the above-mentioned research in Hungarian legal sinology commenced and was perpetuated. Although, this was delayed in line with the recognition of the significance and unnegligibility of PRC by the Hungarian political and economic elite after the change of regime, which did have consequences. ${ }^{3}$

In what follows we will apply the method that first we will introduce the annals history of Chinese reforms, while focusing on the major intersections, then, the processes of the constitutional reform, the administrative (including civil service) reform and finally, the reform of civil law will be elucidated.

2 See the video recording of the speech of Wen Jiabao, Prime Minister of PRC in Chinese at the Davos Annual Meeting 2009 of the Davos World Economic Forum at the following link:

$\mathrm{http} / /$ www.youtube.com/watch?v=Rs9fqfvYiXw (last visited on 20.12.2009). At that time, in comparison with the GDP figure in 2008, an annual growth of $8 \%$ was predicted for 2009 with regard to the difficulties.

3 This is unambiguously highlighted by the following quotation from an authentic Hungarian sinologist: "By the mid-1990s, the circumstance that Hungary became the Central-Eastern-European centre of the distribution network of Chinese goods was a free gift of history. Despite the historical aspiration of Hungary to become the economic-financial hub of the region, we could not take advantage of this stroke of luck and practically, we did not even recognise this fact. It was only after a decade's delay that Hungary attempted to transform into a Chinese bridge-head in the EU, when we had largely missed the opportunity under the changed circumstances. As for the current scope of action, the accommodation of the Chinese whole-traders enriched here as full members in Hungarian society could be accomplished, which could prevent their abandoning the country by withdrawing their wealth, as well." We need to mention that the sinologist author had held this opinion before the public recognition of the moment (15 September 2008: Lehmann Brothers, the fourth largest commercial bank of the USA pleaded Chapter Eleven) of the process of the global financial crisis proceeding from the subprime mortgage crisis and expanding into the world economic recession of 2008-2009. It is also intriguing that all this supervened about 80 years after the Great Depression of 1929-1933, thereby justifying economic cycle theories. Quotation from: Polonyi, P.: Gondolatok a magyarországi kínai kolóniáról (Thoughts about the Chinese Colony in Hungary). In: Polonyi, P.: Múlt a jövőben. Írások Kínáról (Past in the Future. Essays on China). Budapest, 2007, 301. Nevertheless, the fact that the Yingke-Várnai Law Firm, that is, the first legal enterprise expanding in Europe besides PRC opened in Hungary in mid-September 2010 can be acknowledged as a positive development. 


\section{The Antecedents and Commencement of the Reforms}

The outset of the "Reform and Openness" policy (in Chinese: Zhongguo de gaigé kaifang) is disputed. The death of Mao Zedong (1893-1976) can be regarded as a major antecedent of evolution of the reform process, which struck the 82-year-old party leader on 9th September 1976 subsequently to protracted illness occurring after a heart attack. ${ }^{4}$ (Mao had been the number one leader of the Chinese Communist Party (in Chinese: Zhongguo Gongchan Dang) (hereinafter: CCP) for 41 years out of its history of 55 years at that time, being one of the handful founding members numbering 12 according to mistaken tradition, in fact, their number was 13). ${ }^{6}$ Several candidates were prepared to assume power after the death of the dictator including the notorious Gang of Four (in Chinese: Siren bang; in

${ }^{4}$ More amply, see Gernet, J.: Le Monde chinois. Gallimard, Paris, 1972, 502-503; Popov, A. P.: Политические системы и политические режими в Китае XX века (Political Systems and Political Regimes in China in the $20^{\text {th }}$ Century). Moscow, 2007, 174-175.

5 Officially, the Party was established on 1 July 1921 by Chinese Marxists educated in the socalled "Fourth of May Movement" under the influence of the Russian Bolshevik Revolution of 1917. Initially, more significant figures of the movement included Li Dazhao and Zhen Tuhsiu. Concerning the public and party history between 1949 and 1976 see Saich, T.: Governance and Politics of China. New York, 2004, 25-56.

${ }^{6}$ In fact, 12 delegates represented 53 founding members; the former ones can be partially identified by name in the Russian source-material: „Коммунистическая партия Китая была основана в 1921 году в качестве кружка единомышленников. Официально партия ведет отчет своей истории с I съезда состоявшегося нелегально в конце июня-начале июля 1921 года в Шанхае. На съезде присутсвовало 53 человека, в том числе 12 делегатов. Съезд провозгласил конечной целью партии построение в Китае социализма. Ключевую роль в съезде и создании партии сыграли Ли Дачжао, Чэнь Дусю, Чэнь Гунбо, Тань Пиншань, Чжан Готао, Хэ Мэнсюн, Лоу Чжанлун и Дэн Чжунся. На съезде в качестве одного из двух делегатов от провинции Хунань присутствовал и Мао Цзэдун. Среди других участиков съезда были Дун Биу, Ли Ханьцзюнь, Ли Да, Чэн Таньцю, Лю Жэньцзин, Чжоу Фобай, Хэ Шухэн, Дэн Эньмин, а также два представителя Коминтерна." “Тhe Chinese Communist Party was founded in 1921 as a group of associates. Officially, the party has kept records of its history since its Congress held illegally at the end of June and early July 1921 in Shanghai. The Congress was attended by 53 people including 12 delegates. The Congress proclaimed the ultimate purpose of the Party: building socialism in China. The key roles in the Congress and the establishment of the Party were fulfilled by Li Dachrao, Chen Duxiu, Chen Gunbo, Tan Pingshan, Zhang Guodao, He Mensun, Lou Zhranlun and Deng Zhongsa. The Congress was attended by Mao Zedong as one of two delegates from Hunan Province. Other regional congressmen included Tung Biwu, Li Hanqun, Li Da, Chen Danxiu, Liu Renqing, Zhou Fobai, He Shuhen, Deng Yenmin as well as two representatives of the Comintern."

See История Коммунистической партии Китая (History of the Chinese Communist Party) entry at http://ru.wikipedia.org/wiki/История_Коммунистической_партии_Китая (last viewing: 1 January 2011).

According to the second source, seven communist groups included approximately 60 members and the number of the delegates was 13. The second source names the following delegates: Zhang Guodao, Liu Renqing (from Beijing); Li Hanqun, Li Da (from Shanghai); Tung Biwu, Chen Danxiu (from Wuhan); Mao Zedong, He Shuhen (from Changsha); Deng Yenmin, Wang Qinmei (from Xian); Chen Gunbo, Bao Huisheng (from Canton/Guangzhou); Zhou Fobai (from Tokyo). The key figures of the CCP-movement, Li Dazhao and Zhen Tuhsiu stayed away from the Congress. In the work of the Congress Mr. Maring (from the Comintern) and Mr. Nikolsky (from the Profintern) participated, however, according to the second source, Nikolsky is a pseudonym. See Glunin, V. I. (ed.): A Kinai Kommunista Párt története 1921-1969 (History of the Chinese Communist Party 1921-1969). Budapest, 1974, 18, 601. 
Russian: Банда четырёx), ${ }^{7}$ however, Mao Zedong appointed his successor in his life, ${ }^{8}$ scilicet, Hua Guofeng (1921-2008), who became the party leader and (formally) the President of the Central Military Commission, but he was never assigned to the latter position. ${ }^{9}$ During his rule, Hua took the advice of the more sober part (less supportive of the Great Proletarian Cultural Revolution) of Chinese military leadership (still alive veteran generals). The "Gang of Four" was so reckless that they spread in the groves of the party about Hua that he was an uneducated rural cadre, whose promotion could be attributed to being a party secretary of the native village of Mao Zedong, ${ }^{10}$ where he had established a Mao Museum constituting a place of pilgrimage, therefore, he had risen through the ranks. Consequently, the military leadership, especially Marshall Je Jianying supporting Deng Xiaoping rapidly convinced Hua that the "Gang of Four" may induce a situation of civil war, therefore, they quoted the 1968 Party Decision of CCP, which stipulated expressly that a situation of civil war needed to be prevented by all means. Therefore, the "Gang of Four" was arrested on the night from $6^{\text {th }}$ to $7^{\text {th }}$ October 1976, which had been hastened by the news received from Shanghai (the nest of the gang) that the local people's militia had been preparing the way for a takeover of power. By that time, however, the gang had itself understood the weakness of its position. By the time the trial of the "Gang of Four" was instituted (it lasted from November 1980 to January 1981), ${ }^{11}$ the $5^{\text {th }}$ National People's

7 Allegedly, the gang was designated by reason of their manifest power aspirations and intriguing disposition by Mao Zedong himself, who initially and partly supported the formation established as "The Sanghai Group", which opposed primarily Zhou Enlait and Deng Xiaoping. The members of the group were extreme left cultural revolutionaries, otherwise four members of the Political Committee of CCP: Jiang Qing, who died at the age of 77 in 1991 (i.e. Mao's fourth wife known as "Madame Mao" in the West); Zhang Chungqiao, Yao Wenyuan as full members of the Political Committee, finally, Wang Hongwen as a co-opted member of the Political Committee. Saich: op. cit. 54. sqq.

8 This is justified by written proof. The seriously ill dictator in his last days was practically unable to speak; therefore, he issued orders in writing. Presumably, the small scrap of paper (without an addressee) dates from May 1976, which in the unmistakably peculiar and hardly falsifiable handwriting of Mao reads as follows: "(On condition that) You manage matters, I'll be reassured." (in Chinese: Ni zou shih, wo fang xin). The photocopied version of the scrap of paper made the headlines of all Chinese newspapers on the day following Mao's death.

9 Jordán, Gy.: Kina története (The History of China). Budapest, 1999, 388.

10 His homeland was Shaoshan in Hunan province. For more ample data about this administrative unit in English, see Shaoshan as a Wikipedia entry in English: http://www.wikipedia.org/wiki/ Shaoshan (last visited: 20 December 2009).

11 During the trial, the Gang of Four and formerly arrested persons (ten military leaders) belonging to the group of the "Lin Biao conspirators", furthermore, the personal assistant of Mao, Chen Boda (1904-1989) were indicted. Besides being the lawful revelation of the Cultural Revolution, the trial conducted by special judiciary was simultaneously a show trial broadcasted by the state television for two months, owing to which the principal defendants were convicted. Jiang set up the mere implementation of Mao's orders as a defence. Nevertheless, the trial did not conclude in the strong condemnation of Mao's activity, whereas, not only the accused but also the extraordinarily pestiferous and utterly meaningless Cultural Revolution was also condemned. As an outcome of the trial, the principal defendants were found guilty for the persecution of up to 730,000 people and the death of 35,000 people. Jiang Qing (Madame Mao) and Zhang Chungqiao were sentenced to death, but the execution of the sentence was suspended and in 1983 it was commuted to life imprisonment. The other accused were condemned to $16-18$ years' imprisonment. The "show" nature of the trial is unequivocally exposed by the following text: "In 1981, the four deposed leaders were subjected to a 
Congress (Chinese Parliament) during its third session between $30^{\text {th }}$ August and $10^{\text {th }}$ September 1980 relieved Hua Guofeng of his office as a Prime Minister (but he was only later dismissed from senior leadership during the Congress of CCP in September 1982), who was replaced by Zhao Ziyang (1919-2005) for the period of 1980-87. Policy-making became finally controlled by the genuine successor of Mao, the pragmatist Deng Xiaoping (1904-1997), who was appointed to be the third president of CCP (the position was not occupied between 1976 and 1978).

Around December 1978, 18 Chinese peasants organised a secret night gathering with advance arrangements in the village of Xiaogang in Anhui province (in China, secret gatherings, religious associations, political societies and movements date back traditionally to ancient times). However, this one was a so-called formless gathering (in Latin: concio), where the participants agreed that they would withhold the product surplus and would not contribute it to the collective, whereas, they would carry on paying mandatory taxes and arising costs. Later, politicians approved of the matter posteriorly. There may have been other similar actions, at any rate, this went down in history and can be deemed to be the outset of the thirty years' reforms. However, it apparently was not a conscious commencement, those who participated did not suspect what they were initiators of and the reforms would not have amounted to much unless politics traced back the beginnings to this event and the political historical events, which we will elucidate in the following. ${ }^{12}$

A significant antecedent consists in the "Ten Years' National Economic Development Program" based on the experience of the economic boom of 1977 and designed for the years of 1976-1985, the basis of which had been elaborated already in 1974. The Program was adopted by the $2^{\text {nd }}$ Plenary Session of the $10^{\text {th }}$ Central Committee of CCP held between 18-23 February. ${ }^{13}$ The $3^{\text {rd }}$ Plenary Session of the $11^{\text {th }}$ Central Committee of CCP (18-22 December 1978) meant the "tensile test" on the one hand between the orthodox extreme left and the Maoist party workers promoting the Cultural Revolution aligned with Hua Guofeng, on the other hand, the centrist realist forces clustered around Deng Xiaoping considered right-wing (within the party). Some years later, this plenum was reasonably declared a milestone by writers of party-history, since this led to the evolution and consolidation of the "Reform and Openness" policy. At that time, the main slogan besides personal rehabilitations (which remarkably and massively rehabilitated a proportion of the politicians persecuted preceding the Maoist Great Proletarian Cultural Revolution (in Chinese: Wúchănjiējí Wénhuà Dàgéming) was "socialist modernisation" and the "Ten Years' National Economic Development Program" designed for the years of 1976-1985 by Hua was not even mentioned, whereas, it anticipated a demand for change. At the same time, the session bestowed great attention on the issues of the democratic rights of the masses, the freedom of criticism, the reinforcement and extension of democracy and the legal order, furthermore, on the restoration of legality. Following the polemical article of a social scientist, the issues "whether the only criterion of the establishment of truth is indeed a practice", ${ }^{14}$ furthermore,

show trial and convicted of anti-party activities". See Gang of Four (Wikipedia entry in English) at http://en.wikipedia.org/wiki/Gang_of_Four (last visited: 20 December 2009).

12 The policy of "Reform and Openess" is expounded in extensive Hungarian literature see Jordán, Gy.-Tálas, B.: Kína a modernizáció útján a XIX-XX. században (China on the way of modernisation in $19^{\text {th }}$ and $20^{\text {th }}$ century). Budapest, 2005, 255-348.

13 Jordán-Tálas: op. cit. 238. sqq.

14 This was raised in opposition to the following formula of Hua Guofeng published in Renmin Ribao on 7 February 1977: "Whatever President Mao's decision could be, we will support it, whatever 
"whether truth should be sought after starting from facts" were raised. The participants deemed it important that the people's way of thinking should be liberated since: "If everybody in a party, in a country and within a nation acts verbatim, the way of thinking will harden, progress will become impossible, life and the party will come to an end and the country will decline". At any rate, the imperishable merits of Mao Zedong were recorded with the comment that the demand that a revolutionary leader should be impeccable is not Marxist. ${ }^{15}$

It is debated even in technical literature which year should be regarded as the first year of the reforms. A Russian source in a renowned journal of legal studies points out that the initial year of the reforms was 1978. ${ }^{16}$ The article of a Chinese author written in English and published in a prestigious journal of public administration considers 1979 to be the initial year of the reforms. ${ }^{17}$ We deem it important to point out that the prevalence of the reform became practically manifest only by 1980 and its outset was only subsequently established. Therefore, it is very appropriate to mark the years of 1978-1979 as "a continual beginning", which entailed amazing changes in the life of PRC. ${ }^{18}$ These processes are designated as Leninist Transitions by certain Western scholars ${ }^{19}$ (Although, in our view, the system of the Chinese Proletarian Dictatorship was rather peculiarly Chinese and later much more and expressly Maoist than Leninist. Instead of Leninist, Marxist-Leninist would have been the appropriate terminology according to the concepts of scientific socialism.)

guidance President Mao gave us, we will unwaveringly follow it". This was the so-called formula of the "two whatevers" (in Chinese: liang ge fanshi), concerning which Deng Xiaoping declared in May 1977 that it did not comply with Marxism. Concerning the formula see Jordán-Tálas: op. cit. 236. On the statement of Deng see Deng, X.: "Liang ge fanshi" bu fuhe makesizhuyi (The "two whatevers" does not meet the Marxism). In: Deng Xiaoping Xuanji (1975-1982) (Selected Works of Deng Xiaoping, 1975-1982). Beijing, 1983, 35-36. Quoted in Jordán-Tálas: op. cit. 237, footnote 2. On the assessment of Hua's policy see Saich: op. cit. 55-56.

15 On the quotation, see Zhongguo Jingji Nianjian (China Economic Yearbook). 1981, II/24.

${ }^{16}$ Kumanin, E. V.: Китайское право в условиах реформ (The Chinese Law from the perspective of the reform). Советское государство и право, 61 (1988) 9, 91 sqq.

17 You, Ch.: Current Administrative Reform in China. International Review of Administrative Sciences, 52 (1986) 3, 123 sqq.

18 For example, it suffices to mention concerning city development that Shanghai with up to 17 million permanent and 4 million temporary residents has become the financial centre of the Far East, or we could refer to Shenzhen under Deng, formerly a fishing village, then a megapolis has become part of the Special Economic Zone mainly because it borders on Hong Kong. In the recent two decades, 30 billion USD has flown into this city, which is currently the largest harbour of China and one of the most dynamically developing cities of the world. Today it has a population of approximately $8,700,000$. Within its population, the proportion of people under 30 is strikingly high, while $20 \%$. of the Chinese Ph.D. holders live here. In 2011, Shenzhen accommodated the 26th Summer Sports Universiade. An important source concerning Shenzen: Má li Shenzhen. Glamourous Shenzhen. Shenzhen shi renmin zhenhfu xinwen hangong shi. Shenzhen, 2009, 24. (with a supplementary Chinese-English CD).

19 Winckler, E. A.: Describing Leninist Transitions. In: Winckler, E. A. (ed.): Transition from Communism in China. Institutional and Comparative Analyses. Boulder (COL, US)-London, 1999, 3-48; Winckler, E. A.: Explaining Leninist Transitions: In: Winckler, E. A. (ed.): Transition from Communism in China. Institutional and Comparative Analyses. Boulder (COL)-London, 1999, 259294. 


\section{The Constitutional Reform}

Both the traditional Chinese legal system, ${ }^{20}$ scilicet, the imperial period of China (221 B.C. -1911 A.D.) recognised and the legal systems of the Chinese Republic (1912-1949) as well as of the currently prevailing People's Republic of China (since 1949) have incorporated the legal institution of a written constitution. The enumeration of the Chinese written constitutions is not an easy task. ${ }^{21}$ For a long period, France used to exist in such a constitutional uncertainty just as the People's Republic of China did between 1954 and 1982, when it had four written constitutions within a short period of 28 years (according to the sources: state constitutions), however, we need to mention that the state constitution of 1982 (hereinafter: the Constitution) has been practically in force for so many years. The significance of constitutional law in China (in Chinese: xianfa) is increasing. With regard to their longevity, we can claim that the Constitution is in compliance with the reforms. Therefore, we will expound the pre-history of the effective Constitution more amply.

The draft of the Constitution was subjected to a four-months' national debate on 28 April 1982. Formerly, the National People's Congress had appointed a Constitutional Review Committee of 100 members on 7 September 1980. Beng Chen, the Vice-President of the Constitutional Review Committee specified the most important basic principles of

${ }^{20}$ See technical literature on the topic: Balazs, É.-Maspero, H.: Histoire et institutions de la Chine ancienne des origines au XII e siècle après Jésus-Christ. Paris, 1967, 303. passim. Bodde, D.Morris, C.: Law in Imperial China. Exemplified by 190 Qing Dynasty Cases. With Historical, Social, and Judicial Commentaries (Translated by the Xingan Huilan). Cambridge (MA), 1967. XIII, 615.

21 The constitutions are enumerated chronologically in the following works of English-language technical literature written by Chinese authors: Zhian, T.: The Government and Politics of China. Cambridge (Mass.), 1950, 435. Concerning constitutional history in the republican age see Chen, R.: Zhongguo xianfa shi (History of the Chinese Constitution). Shanghai, 1933; Kuhn, P. A.: Les origines de l'Etat chinois moderne. Paris, 1999, 205; McHenry, R. (ed.): Britannica Hungarica Világenciklopédia (Britannica Hungarica World Encyclopaedia).Vol. 10, Entry China. Budapest, 1998, 483. Column 2: refers mistakenly to the first Constitution of 1908 as a new constitution put in force by the Manchurian Court in 1906. Concerning the Constitution of 1946 see Peaslee, A. J. (ed.): Constitutions of Nations. Vol. I. From Afghanistan to Finland. The Hague, 2nd ed., 1956, 506-515. For the text of the constitution: ibid. 515-535. See the Constitution of 1946 in Taiwan: A Brief Introduction to the Republic of China. Taipei, 1998, 19. sqq. Concerning the Constitution of 1954 see Popov: op. cit. 197-202; Su, J.-H.-Tomson, E.: Regierung und Verwaltung der Volksrepublik China. Köln, 1972, 17-36, 70-113. According to our knowledge, the whole text of the Constitution of China of 1954 was published in Hungarian see Zhou, E.-Liu, S.-Mao, Z.: A Kinai Népköztársaság Országos Népi Gyülésének I. ülésszaka 1954. szeptember 15-28. A Kinai Népköztársaság alkotmánya (The First Session of the National People's Congress between 15-28 September 1954. The Constitution of the People's Republic of China). Budapest, 1954. Concerning the constitution of 1975 see Popov: op. cit. 202-203. Concerning the constitution of 1978 see Lesage, M.: Les institutions Chinoises. Paris, 1978, 21; Popov: op. cit. 203-221. Concerning the (effective) Constitution of 1982 see Popov: op. cit. 221224; Jakóbiec, W.-Rowinski, J.: System konstytucyjny Chinskiej Republiki Ludowej (The Constitutional System of the People's Republic of China). Warsaw, 2007, 98; Saich: op. cit. 123-124. and passim. Separate monographs expounding the subject: Lin F.: Constitutional Law in China. Hong-KongMalaysia-Singapore, 2000, 378; Palmer, M.: The Chinese Constitution. A Contextual Analysis. Oxford, 2011 (publication in process). 
the future basic law: insistence on the four (basic) principles, ${ }^{22}$ the principal task of the Chinese people is to focus its efforts on socialist modernisation, the development of socialist morals is indispensable for material development, the basic rights of the citizens shall be safeguarded in compliance with socialist democracy and the socialist legal system, the system of people's gatherings shall be reinforced and the scope of their power shall be extended, ethnic autonomy shall be developed, basic-level political power shall be reinforced etc. Special emphasis was placed on equality before the law, the protection of personal dignity, on the principle that no organisation or individual shall enjoy rights unless they are guaranteed under the constitution or separate law and on the requirement of the reinforcement of the socialist economic system. Finally, the constitution was adopted by the $5^{\text {th }}$ Session of the National People's Congress on 4 December 1982. At that moment, the constitution contained 138 Articles divided into 4 Chapters: I. General Principles, II. The Basic Rights and Obligations of the Citizens, III. The Organisation of the State, IV. The National Flag, the National Coat of Arms and the Capital. The Constitution as promulgated was published in Hungarian translation relatively soon, but it was not easily accessible. ${ }^{23}$ It is worthwhile to expand on the four major (comprehensive) constitutional amendments before engaging in the actual analysis. ${ }^{24}$

\subsection{The First Amendment of 12 April 1988}

The new amendment of Art. 11 sets forth: "The state shall permit the existence and development of the private sector of the economy within the limitations prescribed by law. The private sector of the economy shall be complementary to socialist public economy. The state shall protect the lawful rights and interests of the private sector of the economy and shall exercise guidance, supervision and control over the private sector of the economy". ${ }^{25}$ Jordán claims that this amendment reinforces the legal status of the private sector so that

22 We need to expand on the above-mentioned so-called four principles (Four Cardinal Principles, in French: quatre principes fondamentaux) contained under the Constitution. These are as follows:

- The Principle of the Leadership of the Communist Party; in French: La reconnaissance du rôle dirigeant du Parti communiste chinois,

- The Principle of the Guidance of Marxism-Leninism and Mao Zedong Thoughts; in French: Les instructions du marxisme-léninisme et des idées du Mao Zedong,

- The Principle of the People's Democratic Dictatorship; in French: L'attachement á la dictature démocratique populaire,

- The Principle of Adherence to Socialism; in French: L'attachement á la voie socialiste.

See Lin: op. cit. 25-35. (points 2.06.-2.13.); Bányai, L.: Quelques problèmes de la modernisation du système politique de la République Populaire de Chine. In: Lukic, R. (ed.): La modernisation du droit. Beograd, 1990, 6.

${ }^{23}$ MTI International Documents, 26 (1983) 3, 3-25. Currently, the Hungarian translation of the significantly amended Constitution and its annotation are under publication. See the English-language version of the constitution: The Constitution of the People's Republic of China. Beijing, 1983. See further one of the Chinese text editions: Zhonghua Renmin Gongheguo Falu Fagui Quanshu, 1 (1994), 20. sqq.

${ }^{24}$ Popov: op. cit. 221. sqq. passim. Jakóbiec, W.-Rowinski, J.: op. cit. 34. Only the Polish source mentions the exact dates of the $3 \mathrm{rd}$ and 4 th amendments.

25 The earlier text was this: "No organisation or individual may appropiate, buy, sell, or lease land, or otherwise engage in the transfer of land by unlawful means." 
the private sector shall function as a supplement to the state sector. ${ }^{26}$ Lin highlights the following amendment (Para. 4) of Art. 10: "No organisation or individual may appropriate, purchase, sell or otherwise engage in the transfer of the land by unlawful means. The right to the use of the land may be transferred according to law". In the opinion of Lin, the recognition of the existence of the private enterprise and the private sector and the regulation of the transfer of the right of the use of land are of crucial importance. The amendments reveal that Chinese economy tends to be market-oriented and some socialist dogmas have been replaced by practical thinking. ${ }^{27}$

\subsection{The Second Amendment of 19-29 March $1993^{28}$}

The 1993 Amendment amounted to changes in the constitution at nine points (Lin). According to the technical literature at our disposal, it is only Jordán who outlines three highly significant amendments of the preamble seeming inconsequential at first sight. As Jordán formulates: "The amendment adopted on 19 March 1993 declared in compliance with the turning point supervening in economic policy in 1992 that China shall abide by market economy instead of planned economy, nevertheless, it also included other important supplements". The requirement of building socialism with Chinese characteristics, which is basically applicable in nearly all respects, was incorporated in the section of the preamble stipulating the tasks of socialist modernisation. Mentioning Chinese characteristics, features or quality does not only refer to the consideration of the conditions and features of China upon seeking solutions, but this is also a manifestation of Chinese nationalism becoming more and more determinant. Other phrases of the amendment highlighted democracy and building a democratic socialist nation. This manifests itself in the following amendment: "The system of multi-party cooperation and political consultation led by the Chinese Communist Party shall prevail and develop in the distant future, as well". The Preamble was also supplemented by a short affirmative sentence: "China is at the primary stage of socialism". The statement, which does not seem to be too consequential, had had a relatively long prehistory, but the conclusions and references deriving from it are even more important. The incorporation of the tenet into the constitution was actually delayed, since it was the theoretical conclusion of the $13^{\text {th }}$ Congress of CCP at the end of October 1987 that China was at the primary stage of socialism and this feature would mark at least the next 100 years as of the 1950s. The tenet secured a relatively wide scope of action to government as

26 Jordán: „Az ég magas, a császár messze van.” Igazságszolgáltatás, jog, és politika Kinában ("The Skies Are High, the Emperor is Far Away." Jurisdiction, Law and Politics in China). Budapest, 2008, 208.

27 "They are concerned with the economic system and with the intention to legitimise the prevalence of private enterprise and the transfer of land-use rights. These amendments have demonstrated that Chinese economy is more market-oriented and that some of the socialist dogmas have given way to pragmatism." Lin: op. cit. 17. (Point 1.23.). The Polish publication on the amendment of 1988 is in accordance with the other two sources with respect to private enterprise: "W nowelizacji z 1988 roku uznano sektor prywatny za uzuplenienie gospodarki opartej na systemie wlasnosci publicznej (Art. 11)." In English: "In Amendment of 1988, the private sector was a complementary economy-based system of public ownership (Art. 11)". Jakóbiec-Rowinski: ibid.

2819 March 1993 is mentioned: Jordán: „Az ég magas ...” op. cit. 208; 29 March 1993 is specified as the date of the amendment: Jakóbiec-Rowinski: ibid. The contradiction currently cannot be dissolved in a reassuring manner, since the other sources at our disposal ignore the specification of dates. 
for its basic economic and political reform steps and their ideological acceptance. This could be quoted upon the widespread permission of private enterprise and the private sector, upon the application of other forms of distribution (profit, dividend etc.) besides distribution according to "socialist" work, upon taking over certain capitalist methods (instead of the former total contraposition of capitalism and socialism) and upon the justification of the admission of foreign operating capital funds and other forms of cooperation (Jordán). Our Polish source highlights terms in re the supplementary law of 1993 such as the "Reform and Openness" [policy] (in Chinese: gaigé kaifang; in Polish: reformy i otwarcie), socialism with Chinese characteristics (in Chinese: you Zhongguo tese shehuizhuyi; in Polish: socjalizm o chinskiej specyfice).

Under Art. 7, issues concerning the state sector of the economy are regulated. Here, instead of "expansion" of the sector, the word "development" is used, since the reform entailed dwindling and massive shrinking of the economy supervised by the state (Jordán).

Under Art. 8, the rural commune having dissolved a decade before (at the beginning of the 1980s) was replaced by the system of rural contractual liability. Jordán restricts himself to the assessment of the amendments under Arts 15 and 17, whereas, the Polish volume expands on the amendment of Art. 16, as well. Under Arts 15 and 17, the term of planned economy and those pertaining to state planning were deleted. Art. 15 regulates issues related to the public sector of the economy. The new version uses the expression "strengthening" instead of the former "growth" in connection with economic sector. The reform in this case means diminishing planned economy (economy supervised by the state). ${ }^{29}$

Under Art. 16, rural communes dissolved at the beginning of the 1980s were replaced by the system of rural contractual liability.

Our Polish source outlines the amendments pursuant to Art. $16 .{ }^{30}$ From Arts 15 and 17, the terms of "planned economy" and "state planning" were deleted.

Paragraph 3 of Art. 42 was amended, as well. The term of "state enterprise" was changed to "state-owned enterprise". 31

As Art. 98 stipulated: "The term of mandates at the people's congresses at the regional level shall be five years". Whereas, the term of mandates at the lowest level of people's

29 Article 15: The state shall accomplish socialist market economy. The state shall strengthen economic legislation and improve macro-economic supervision. State laws shall prohibit disturbance of the social-economic order by any person.

30 Article 16: State-owned enterprises shall accomplish management by themselves within the limitations prescribed by law. State-owned enterprises shall implement democratic management via congresses of workers' representatives and in other ways in accordance with the law.

Article 17: Collective economic associations shall conduct economic activities independently and have decision-making powers in compliance with relevant laws. Collective economic associations shall implement democratic management and assign or recall the members of management as well as decide on major issues of organisation management in accordance with the law. In the territory of China, foreign companies and other foreign economic associations such as Chinese-foreign joint ventures shall observe the laws of the People's Republic of China. The lawful rights and interests of joint ventures shall be protected by the laws of the People's Republic of China.

31 Article 42: Work shall be a matter of honour for every citizen who is able to work. All the people working in state-owned enterprises as well as in urban or rural economic collectives shall relate to their work as masters of the country they are citizens of. The state shall promote socialist labour emulation as well as shall commend and reward exemplary and outstanding workers. The state shall encourage citizens to take part in voluntary labour. 
congresses remained three years. ${ }^{32}$ In case of the people's congresses of counties and administrative units of the same level, the term was raised to five years, just as the term of the mandates at people's congresses of the provinces and at the People's National Congress, scilicet, Chinese Parliament lasted. ${ }^{33}$ Lin does not expand on the amendment in detail, although, he mentions that it was conceived in the spirit of the socialism with Chinese characteristics and market economy. The 1993 Amendment demonstrated that CCP was genuinely following the way of lawful procedure. ${ }^{34}$

\subsection{The Third Amendment of 15 March 1999}

According to Lin, six amendments were made, out of these, Jordán and our Polish source mentions four ones. It was the $15^{\text {th }}$ Congress of CCP that made a decision on the amendments. They included "the theory" of "the eternal pragmatist", Deng Xiaoping among the basic principles under Section 7 of the Preamble besides the concepts of Mao Zedong. The basic principle of the rule of law (in Polish: rzady prawa or praworzadnosc) ${ }^{35}$ was incorporated under Para. 1 of Art. 5 as an eloquent proof that China shows due regard not only for continental law, but also for Anglo-Saxon law. Three amendments concerned the transition to the Chinese-type market economy, whereby the private sector was declared to be an important and equal component of market economy instead of being a supplementary component of socialist economy. On such grounds, the dominance of distribution according to labour under Art. 6 was qualified, since it shall co-exist with other methods of distribution. Article 11 regulates the above-mentioned reinforcement of private enterprise, accordingly, the original phrase "The private enterprise of municipal and rural workers, which shall operate within the limitations of law, shall be a supplement to the publicly-owned socialist enterprise" was replaced by what follows: "The individual, private and other not publiclyowned enterprise, which shall exist within the limitations of law, shall be major components of socialist market economy". Furthermore, it also anticipated the protection of the state for both the individual and the private enterprises. ${ }^{36}$ In accordance with the amendment of the Chinese Criminal Code, the reference to counter-revolutionary crime was deleted from Art. 28 , instead, the phrase of crime threatening national security has been introduced. ${ }^{37}$

\subsection{The Fourth Amendment of 14 March 2004}

Zhiang Zemin's ideology of the Three Represents' (in Chinese: Sāngè Dàibiăo; in Polish: trzech reprezentacji) was adopted in the Preamble of the amended Constitution. This ideology legalised the possibility of party membership for most capitalists. The reason was as follows: "The party should represent progressive productive forces, as well" (this is

32 The lowest levels refer to the people's congresses of townships, ethnic townships and towns.

33 On the Amendment of 1993, see Lin, op. cit. 18. (Point 1.23a.); 87. (Point 4.14.). JakóbiecRowinski: op. cit. 35 .

34 On the Amendment of 1993, see Lin: op. cit. 18. (Point 1.23a.); 87. (Point 4.14.). JakóbiecRowinski: op. cit. 35.

35 The rule of law and the Rechtsstaat are not the same concepts. The Rechtsstaat is a typical concept of continental law (specifically, of German law). It can be translated into English as the "legal state" or the "state of law", but it cannot be referred to as the "rule of law" in English texts.

36 Jordán: „Az ég magas ...” op. cit.; Jakóbiec-Rowinski: op. cit. 36-37.

37 Lin: op. cit. 18. (Point 1.23a.), 364-365. See English version of the Third Amendment, Art. 16 as amended. 
antagonistically contrary to the principle of class struggle of Maoism). The provision of Art. 10 was supplemented as follows: "[...] the legally obtained private property of citizens shall not be violated". Article 11 promotes the most powerful protection of market economy. Article 13 protects more accentually the right of citizens to inherit private property. Article 14 supports building the social security system. Paragraph 1 of Art. 33 contains a new sentence of historical value: "The state shall respect and protect human rights". Under Art. 67 , the new expression of "state of emergency" appears in line with the former one of "state of war". This new concept modified the roles of the President of PRC and the State Council (Arts 80, 89). Article 98 extends the term of mandate in all the lowest level (local) people's congresses to five years. ${ }^{38}$ Article 136 stipulated that the Chinese national anthem shall be March of the Volunteers (in Chinese: Yìǒngjūn Jinxingqǔ; in Polish: Marsz ochotników); the reason for this affirmation was the lack of reference to Mao Zedong. ${ }^{39}$ In the following, we will analyse two important subject-matters of The State Constitution of PRC.

\section{5. (Self-) Definition of the People's Republic of China (Art. 1)}

According to this section, the People's Republic of China shall be governed by the working class, which amounts to a socialist state of the people's democratic dictatorship (dictatorship of the proletaria $t^{40}$ ), the foundation of which has been laid by the alliance of workers and peasants. It is highlighted that the socialist system is the foundational state establishment, which allows for no departure. The final sentence refers to the destruction of the socialist system, which is prohibited both in re-natural persons (humans) and associations (unity of persons and capital either incorporated or not, scilicet, legal entities and other organisations without legal entity). The text does not point it out, nevertheless, it can be presumed that the prohibition of destruction ${ }^{41}$ refers merely to the ordinary meaning of destruction, not to the criminal legal sense of the term as a fact of the case under criminal law in Hungary pertaining to treason. PRC shall be a single-party state.

\subsection{The basic rights and duties of citizens under Arts 33-56}

With respect to PRC, the issue of basic human rights is of major importance. The Constitution provides basic human rights and duties under the same chapter, which is dogmatically appropriate. However, we need to clear up a misunderstanding, scilicet, that it was revealed upon the translation of the UN Charter that the term of right does not have an equivalent in Chinese. The equivalent of the term of substantive law (in Latin: ius, norma agendi; in English: law) is falü. Indeed, the term of civic rights (in Latin: facultas agendi; in English: right) did not use to have an ingrained equivalent, which could substantiate the divergent construction of human rights (besides a different conception of power).

38 Jakóbiec-Rowinski: op. cit.; Jordán: Kina története. op. cit. 209-210.

39 Jakóbiec-Rowinski: op. cit. 37; Jordán: ibid. 210.

40 This is a typical concept of Karl Marx (in German Diktatur des Proletariats) in Fourth Chapter of Critique of the Gotha Program (in German Kritik des Gothaer Programms) from 1875.

${ }^{41}$ Article 1: The People's Republic of China is a socialist state under the people's democratic dictatorship led by the working class and based on the alliance of workers and peasants. The socialist system is the basic system of the People's Republic of China. Disruption of the socialist system by any organisation or individual is prohibited. 
Nevertheless, these do not amount to the fact that the term of human rights does not have an equivalent in contemporary Chinese, since it means rénquán. ${ }^{42}$

\section{The Constitution specifies the following rights:}

- The right to citizenship (Art. 33),

- Equality before the law (Art. 33),

- The right to vote and the right to be elected (Art. 34),

- The citizens of PRC enjoy freedom of speech, the freedoms of the press and of assembly, the freedoms of organisation, procession and demonstration (Art. 35),

- The freedom of religion (Art. 36),

- Citizenship rights (Art. 37),

- The right to human dignity (Art. 38),

- Inviolability of the residence of citizens (Art. 39),

- The freedom and privacy of correspondence (Art. 40),

- The right to criticism and making suggestions (Art. 41),

- The right to petition (Art. 41),

- Citizens who have suffered losses via the infringement of their civic rights by any state organ or functionary have the right to compensation in accordance with the law (Art. 41),

- The right to work (Art. 42),

- The right to rest (Art. 43),

- The right to retirement (Art. 44),

- The right to material assistance for elderly, ill and disabled persons (Art. 45),

- The right to education (Art. 46),

- Freedom to engage in scientific research, literary and artistic creation and other cultural pursuits (Art. 47),

- Women's rights (Art. 48).

\section{The Constitution specifies the following duties:}

- Every citizen shall enjoy the rights and comply with the duties prescribed under the Constitution and other law (Art. 33),

- The state shall respect and protect human rights (Art. 33),

- The insult, libel, false accusation or false incrimination directed against citizens by any means shall be prohibited (Art. 38),

- The duty of work (Art. 42),

- The duty of education (Arts. 45-46),

- Compliance with the "one child policy", or in official terms with family planning (Arts 25, 49, 107), ${ }^{43}$

- Parents shall comply with the duty to raise and educate their minor children and grown-up children shall comply with the duty to support and assist their parents (Art. 49),

- Violation of the freedom of marriage shall be prohibited, as well as maltreatment of old people, women and children shall be prohibited (Art. 49),

42 See Lu, Y. S. (ed.): The English-Chinese Dictionary (Unabridged) in 2 vols. Vol. I. Shanghai, 1991, 1571, 2. column, entry 8.

43 In Chinese: jihua shengyu literally means "planned birth". 
- PRC shall protect the lawful rights and interests of Chinese citizens residing abroad and of the family members of Chinese citizens residing abroad as well as the lawful rights and interests of overseas Chinese returning home (Art. 50),

- Upon the exercise of their freedoms and rights, the citizens of PRC may not infringe the interests of the state, society, the collective or the lawful freedoms and rights of other citizens (Art. 51),

- Safeguarding the unity of the country and of all its ethnic groups (Art. 52),

- The citizens of the PRC shall abide by the Constitution and separate law, they shall keep state secrets, protect public property, they shall observe labour discipline and public order as well as respect social morals (Art. 53),

- Defence of the motherland and doing military service (Art. 55),

- Paying taxes (Art. 56).

Numerically, 19 rights are juxtaposed with 14 obligations, so that work and education simultaneously constitute rights and obligations. We could meticulously expand on the specific rights and obligations; instead, we will call the readers' attention to technical literature on Chinese human rights. ${ }^{44}$ We cannot fail to mention that the constitutional amendment of 2004 momentously transformed the Chinese catalogue of human rights. Nevertheless, hardly half a decade has passed; therefore, the evolution of considerable judicial practice cannot be expected. Among the criticisms concerning human rights in China, we refer merely to the "problem map" of European Parliament of 2006: it reproaches China with the high number of death sentences (with the comment that all cases in which a death sentence has been imposed in the lower instance are automatically submitted for review to the People's High Court of Justice). The report focuses on politically motivated imprisonment and forced labour. Besides the issue of the freedoms of speech and religion, the Tibetan issue and trade in organs as well as the camp system of Laodong Gaizao (literally "reform through labour") are objected to. ${ }^{45}$

\section{The Administrative Reform}

Formerly we mentioned that in the article of You, 1979 is indicated as the beginning year of administrative reforms. Others argue that the administrative reform commenced in August 1980 with a speech of Deng Xiaoping, ${ }^{46}$ whereas, administrative reforms have been characteristic in PRC since 1949. ${ }^{47}$ The division of Chinese administrative reforms into different periods is well-known, which is partly factual, partly didactic, therefore, its publication cannot be neglected. The following periods of public administrative reforms are

${ }^{44}$ Lin: op. cit. 265-284 (Points 10.32-10.76); Biddulph, S.: Legal Reform and Administrative Detention Powers in China. Cambridge, 2007, 143-145. Cambridge Studies in Law and Society; Saich: op. cit. 266-267.

45 See the following source concerning the human rights report of the European Parliament of 2006: http://www.europarl.europa.eu/sides/getDoc.do?type=IMPRESS\&reference=20070426IPR059 64\&language $=\mathrm{HU}$ (last visited: 20 December 2009).

${ }^{46}$ Burns, J. P.: The Civil Service System of China: The Impact of the Environment. In: Burns, J. P.-Bowornwathana, B. (eds): Civil Service Systems in Asia. Cheltenham (UK)-Northampton (USA), $2001,103$.

47 See the following German technical literature concerning public administration before 19781979 in Su-Tomson: op. cit. 37-69, 114-155, 156-197. 
differentiated: the reform of 1982 (1982-1988); the reform of 1988 (1988-93); the reform of 1993 (1993-1998) and the reforms ever since 1998.

\subsection{The Reform of $1982^{48}$}

This is considered to be the first reform of greater scale entailed by the "Reform and Openness" policy. At that time, the relations between the central administration and local governance, ${ }^{49}$ the aging of civil servants and life-long assignments (mainly due to the Great Proletarian Cultural Revolution) and the over-dimensioned government were all deemed problematic. Within the framework of the reform, the following steps were taken: the economic administration was decentralised and as for the personnel of civil service, both the number of the staff and the respective earmarked budget were decreased. Simultaneously, the "Four Goals" (in Chinese: Si Hua) were introduced, which summarised the desirable qualities of cadres (in Chinese: ganbu) such as revolutionary, young, educated and competent. The State Council, scilicet, Chinese Government, which had been outnumbered only by the Soviet Union as to its personnel, could record a considerable decrease in the number of background institutions and its personnel. Out of the 100 background institutions and agencies, 61 persisted in the 1980s and the personnel decreased by one-third ${ }^{50}$ After 1984, the majority of reforms focused on the local level in rural China. In 1987, Deng announced the introduction of the merit-based-system of civil service. ${ }^{51}$

\subsection{The Reform of 1988}

The reform of the State Council continued after 1988. The number of departments decreased from 45 to 41 and as for background institutions, they decreased from 22 to 19, whereas, the personnel of the State Council diminished by a further $19.2 \%$. The reforms could not be implemented in local governments at the local level at such a scale as it had been planned. The demolition of the traditional planned economy also commenced separately in the scope of municipal reforms and rural reforms, however, the implementation of municipal reforms proved to be more complex. ${ }^{52}$ By 1988 , the number of the personnel of the State Council decreased to $29,600 .^{53}$

48 The processes are elucidated chronologically: Tang, T.: China's Administrative Systems Reforms and Trends in their Development. In: Gordon, M. T.-Meininger, M.-C.-Chen, W. (eds): Windows on China. Amsterdam-Berlin-Oxford-Tokyo-Washington DC, 2004, X-XII.

49 On Chinese local governments see Xiong, Y.: Redefining the Role of Local Governments. In: Gordon, M. T.-Meininger, M.-C.-Chen, W. (eds): Windows on China. Amsterdam-Berlin-OxfordTokyo-Washington DC, 2004, 127-133.

50 Concerning the reform of the State Council see Xiong: op. cit. X; You: op. cit. 138; Koi, Gy: A kínai közigazgatási reform egyes kérdései (Specific Issues of the Administrative Reforms in China). Állam- és Jogtudomány, 47 (2006) 3, 504, The number of the personnel of the State Council decreased from 51,000 to 39,000 . At the end of 1984, the number of deputy ministers decreased from 13 to 4 per department. The number of departments decreased from 52 to 43 . (According to other sources, the exact number is 45 . See the facts about the reform of 1988 in the body text.)

51 Koi: A kínai közigazgatási reform... op. cit. 505.

52 Xiong: op. cit. X-XI.

53 Koi: A kínai közigazgatási reform... op. cit. 504. 


\subsection{The Reform of 1993}

At that stage, the development of socialist market economy was more accentuated, therefore, an important slogan was "the separation of government and enterprises". Macro-economic control and the supervision of associations were increased, whereas, the entitlements of government to direct corporate management were reduced. The number of the general offices of the State Council was decreased from 42 to 1(!). Out of 19 background institutions, 13 were maintained, while the number of government agencies decreased from 9 to $5 .^{54}$ By 1993, the regime of cadres was replaced by the system of civil service, cadres converted into public servants (in Chinese: gongwuyuan), thenceforth, public administration was not based on sheer direct party loyalty. ${ }^{55}$

\subsection{Reforms since 1998}

By the time of the Ninth Five-Year Plan, the reforms had reached a new stage, therefore, new problems started to emerge. The reform of the economic system required the further reform of government functions and the further decrease of the number of background institutions. Since 1998, the essential content of the reforms can be summarised as follows: the importance of macro-economic control, direction of the society and the provision of public services is sustained. Simplification, unification and the principle of effectiveness are fundamental in Chinese public administration and the insistence on the efforts of the numerical decrease of government is characteristic. The distinct allocation of the functions among organisations is encouraged. The legal foundation of the system of public administration should be reinforced. ${ }^{56}$ Due to the reforms of 1998 , the personnel of the State Council were downsized to 16,700 (we should bear in mind that upon its establishment, the personnel numbered 51,000 people, thus, two thirds of that has been cut down. $)^{57}$

\subsection{The Personnel of Chinese Public Administration in figures}

The apparatus of 8 million around 1958 swelled to 18 million by the $1980 \mathrm{~s}$. According to certain sources, this stratum numbers 35 million people today, which amounts to $2.5 \%$ of the total population as opposed to the world average of about $1 \%$. According to the data of 1996, within that stratum 6,285,000 are leaders (from team leaders to ministers), which amounts to $18 \%$ of the total personnel and the number of women is merely 1 million. (In Chinese public administration, the proportion of men is $70 \%$ as opposed to the proportion of women of $30 \%$.)

We can conclude that the issue of the number of the personnel will impose numerous tasks on PRC in the future, as well. ${ }^{58}$ Undoubtedly, the instruments of public administrative law (in Chinese: xingzhengfa) need to be applied to solve the persistent problems.

54 Xiong: op. cit. XI.

55 Koi: A kínai közigazgatási reform... op. cit. 505. Concerning the Chinese equivalent see Koi: A kínai közigazgatási reform... op. cit. 503. On the Reform of 1993 see Gōnggòng guănlì yǔ zhōngguó xíngzhèng găigé. Public Administration and Administrative Reforms in China (Bilingual Monography). [s.1.] [s.a.] 49-93.

56 Xiong: op. cit. XI-XII.

57 Koi: A kínai közigazgatási reform... op. cit. 495-509, 505. Concerning the Chinese equivalent, see Koi: A kínai közigazgatási reform... op. cit. 504.

58 Concerning Chinese civil service more amply, see Koi: A kínai közigazgatási reform... op. cit. 500-507. 


\section{The Reform of Civil Law}

The majority of traditional Chinese law constitutes criminal law, whereas, the minor part is public administrative law. Within this framework, civil law hardly has a role. ${ }^{59}$ In this part, we will examine the creation of the Chinese Civil Code thus, family law, commercial or labour law will be not subject to a detailed examination. ${ }^{60}$

Drafting the first Chinese Civil Code commenced in 1906, when with the involvement of Japanese legal experts, the Qing-dynasty of Manchurian origin launched the compilation of a new criminal code, the first Civil Code and commercial code. The draft was prepared by 1911. The Chinese Civil Code was taking effect gradually between 1929 and $1931 .^{61}$ Before its entry into effect, three parts of the draft had been compiled by 1911, two parts by 1916 and they are known as the Private Law Draft of the Qing-dynasty. ${ }^{62}$ Subsequently to the entries into effect in 1929 and 1931, the law can be regarded as being in full effect only as of $1936 .{ }^{63}$ Its text was published in English ${ }^{64}$ and in Latin, as well. ${ }^{65}$ This Chinese Civil Code has persisted only in Taiwan. ${ }^{66}$ Concerning that Civil Code, Jordán comments that it was based on the Swiss Civil Code, ${ }^{67}$ whereas, Hamza points out the impact of the Japanese Civil Code, the German BGB, the Swiss Civil Code (ZGB), the Swiss contract code (OR), the Siamese Civil Code, the Soviet-Russian Civil Code and of the Turkish Civil Code. Eventually, the law follows the Swiss model of the code unique. ${ }^{68}$ This Civil Code of 1936

59 Concerning Chinese traditional law and Chinese private law effective 3-4 decades ago, see the following main works on comparative law in Hungarian or translated into Hungarian on advice: David, R.: A kínai jog. In: David, R.: A jelenkor nagy jogrendszerei. Összehasonlitó jog (Law in China. Contemporary Great Legal Systems. Comparative Law). From Les grands systèmes de droit contemporains transleted by Nagy Lajosné Dusa Margit. Budapest, 422-433; Hamza, G.: Kína (A Kínai Népköztársaság és Tajvan) (China. The People's Republic of China and Taiwan). In: Hamza, G.: Az európai magánjog fejlödése. A modern magánjogi rendszerek kialakulása a római jogi hagyományok alapján (Trends in the Development of Private Law in Europe. The Role of the Civilian Tradition in the shaping of Modern Systems of Private Law). Budapest, 2002, 301-303. With reference to Chinese civil law and the Civil Code, see Jordán: „Az ég magas...” op. cit. 6, 27, 31, 32, 53-54, 107, 224-225, 234. A study on the method of comparative law see Péteri, Z.: Goals and Methods of Legal Comparison. In: Péteri, Z. (ed.): The Comparison of Law. La comparaison de droit. Selected Essays for the 9th International Congress on Comparative Law. Essais choisis pour le $9^{\mathrm{e}}$ Congrès International de droit comparé. Budapest, 1974, 45-58.

${ }^{60}$ On Chinese family law (and the law of marriage therein separately) in detail see Jordán: „, $A z$ ég magas..." op. cit. 213-240.

61 Hamza: op. cit. 302.

${ }^{62}$ Koi, Gy.: Francia monográfia a modern kínai magánjogról (A French Monograph on Modern Chinese Private Law) [Piquet, Hélène: La Chine au carrefour des traditions juridiques. Bruxelles, 2005, 332.]. Acta Facultatis Politico-Iuridicae Universitatis Scientiarum Budapestinensis de Rolando Eötvös Nominatae, 44 (2007), 233-242, in detail see 237.

63 Piquet, H.: La Chine au carrefour des traditions juridiques. Bruxelles, 2005,118.

${ }^{64}$ See the English-language version: The Civil Code of the Republic of China I-V. Shanghai, 1931. Quoted in: Hamza: op. cit. 301, footnote 369.

65 See the Latin version: Jarre, C. R.: Codex Juris Civilis Reipublicae Sinicae (translatus in linguam latinam). Zhinanfu, 1934. Quoted in: Hamza: op. cit. 301, footnote 369.

${ }^{66}$ Hamza: op. cit. 303; Jordán: „Az ég magas ...” op. cit. 31-32; Koi: Francia monográfia a modern kínai magánjogról ... op. cit. 238.

67 Jordán: „, Az ég magas ...” op. cit. 32.

68 Hamza: op. cit. 302. 
was also called Six Codes (Sexapartitum), since it consisted of six parts. ${ }^{69}$ In 1949, after the formation of PRC, a legal problem emerged. It was the Six Codes (it literally means "Six Code Completed Books" (in Chinese: liufa; in Japanese: Roppo) ${ }^{70}$ that contained the most important six legal codes of the Republic of China (Taiwan). ${ }^{71}$ This is not the same as the Six (Civil) Codes. ${ }^{72}$ Since the Government of PRC in its General Program (Art. 17) ${ }^{73}$ put into force a Directive Overruling the Guomindang Six Code Completed Book, ${ }^{74}$ according to which all the repressive laws, decrees and courts of Guomindang shall be withdrawn. ${ }^{75}$ Since PRC consequently persisted without a Civil Code, the need for drafting a new one emerged urgently. The respective work commenced as early as in $1954 .^{76}$ Following the death of Mao Zedong (1976), four drafts were promulgated between 1979 and 1982, the third one was published in 1981, whereas, the fourth one in $1982 .{ }^{77}$ In 1986 , the document framed between 1980 and 1986 designated as "General Principles of the Civil Law of the People's Republic of China" consisting of 9 Chapters and 156 Articles, ${ }^{78}$ was adopted in 1986 and promulgated as a decree in $1987 .{ }^{79}$ In December 2002, an important step forward was made, scilicet, the draft of the Civil Code was adopted by legislation, the People's National Assembly. This draft is 216 pages long and consists of 1209 sections. It includes the following 9 volumes:

- General Principles,

- Property Law,

- Contracts,

- Human Dignity and Civil Rights,

- Marriage,

- Adoption,

- Law Pertaining to Inheritance,

- The Order of Civil Law Liability,

- International Private Law. ${ }^{80}$

69 Piquet: op. cit. 122.

70 The six Japanese Codes are as follows: The Civil Code (in Japanese: Minpo), The Commercial Code (in Japanese: Shoho), The Penal Code (in Japanese: Keiho), The Constitution of Japan (in Japanese: Nippon-koku-kenpo), the Code of the Criminal Procedure (in Japanese: Keiji-sosho-ho), The Code of the Civil Procedure (in Japanese: Minji sosho-ho).

71 The Six Codes of the Republic of China (Taiwan) are: The Constitution of Republic of China (in Chinese: Xianfa), The Civil Code (in Chinese: Minfa), The Code of the Civil Procedure (in Chinese: Minshi susong fa), The Penal Code (in Chinese: Xingfa), The Code of the Criminal Procedure (in Chinese: Xingshi susong fa), Administrative Laws (in Chinese: Xingzhengfa).

72 Jordán: Kína története. op. cit. 53-54.

73 "All laws, regulations and courts of the Guomindang which oppressed the people shall be overruled."

74 Jordán: Kína története. op. cit. 53.

75 Jordán: „Az ég magas ...” op. cit. 53.

76 Koi: Francia monográfia a modern kínai magánjogról... op. cit. 239, footnote 21 .

77 Hamza: op. cit. 303, footnote 371.

78 Hamza: op. cit. 303; Földi, A.-Hamza, G.: A római jog története és instituciói (History and the Institutions of Roman Law). Budapest, 12th ed., 2007, 131; Koi: Francia monográfia a modern kínai magánjogról ... op. cit. 238.

79 Koi: Francia monográfia a modern kínai magánjogról... ibid.

80 Piquet: op. cit. 201. 
We need to draw the attention to the fact that contracts and the tenets of liability are dealt with separately in the text on general principles. This is practically due to the impact of common law. We can only wish that PRC drafts its Civil Code as soon as possible.

\section{Closing Remarks}

As an outset of this study, we stated that the evolution of Hungarian legal sinology is under a heavy handicap with regard to technical literature both written in Hungarian and translated into Hungarian in comparison for example with historical sinology. Therefore, a compendium with a legal viewpoint concerning the ongoing Chinese reforms for the recent 30 years with special respect to the People's Republic of China prevailing for 60 years would be urgently necessary. Historians and economists (especially those interested in world economy) have specialised in China both at the level of education and research rather than legal scientists flouting processes. This discipline demonstrated some interest in China substantiated by technical literature merely in the 1950s, however, this hardly overreached the scope of descriptive booklets translated from Russian. By this day, however, the People's Republic of China is an unevadable world power, a macro-economic factor and if you please, a factor determining international law. After yielding to the conception of class struggle following Mao's death, the reforms beginning 30 years ago linked up the Maoist state with the elements of social market economy, promoting thereby the fulfilment of the inherent nature of the Chinese peasant population, the majority of whom were born for trading. Our work has elucidated that the outset of the reforms as it was spontaneous cannot be attached either to 1978 or to 1979 , therefore, it was not sparked off either by the secret product surplus appropriating movement or the CCP legitimating such organisations posteriorly, which considered the commencement of the reforms subsequently as a fact. The years of 1978-79 can be deemed as continuous commencement of the reform, in which the crucial role was played by the victory of Deng Xiaoping's pragmatist policy in 1978. This can be construed exclusively in the light of the death of Mao in 1976, who appointed his successor to be the orthodox Marxist Hua Guofeng supporting the Cultural Revolution. Considering the legal policy of the reforms, we examined three areas after an analysis of the historical roots, scilicet, the constitutional reform, the reform of public administration and of civil law. As a result of the reform of constitutional law, the $4^{\text {th }}$ Constitution of PRC $\left(9^{\text {th }}\right.$ Constitution of the state of China) took effect in 1982 during the reforms. It was amended 4 times in 1988, 1993, 1999 and 2004. In the scope of major policies, we need to highlight that socialist market economy has replaced the system of planned economy, as a result, the protection of private property, the effectuation of compensation for expropriation constitute the most essential changes of principle. It was a genuine Copernican turning point in constitutional law that Para. (1) of Art. 33 of the Constitution of PRC in 2004 provided that the state shall protect and respect human rights. We dealt with the reform of public administration in its temporality. Accordingly, 1982, 1988, 1993 and 1998 can be considered the dividing years of the reform, when the number of the staff of Chinese Government, i.e. the State Council implementing services and official functions as well as the number of politicians was massively reduced. The apparatus of the State Council formerly numbering 51,000 members decreased to 16,700 in 16 years (by 66\%). The reforms considerably affected local governance, although the respective figures are less known. Notwithstanding, public administration can still be considered overstaffed.

The reforms of civil law are also significant, the objective of which was drafting new codices after the voidance of the bourgeois laws of the Guomindang. The work commenced in 1954, but the first four drafts were promulgated as late as between 1979 and 1982, 
scilicet, during the period of the reforms. The document designated as the General Principles of the Civil Law of the People's Republic of China was framed between 1980 and 1986, it took effect in 1987 and has been functioning practically as a decree. The draft of the Chinese Civil Code was publicised in 2004. The reforms are bound to continue in the future, as well. However, the current Maoist political trend is unlikely to come to an end. Notwithstanding, the signs of democratisation are manifest in the territory of PRC, as well. 